\title{
光ソリトンの性質を利用した全光可変遅延線とそのシステム応用
}

\author{
丸田章博 \\ 大阪大学 大学院工学研究科 ( 5 565-0871 大阪府吹田市山田丘2-1)
}

\section{All-Optical Tunable Delay Line Using Optical Soliton's Feature and Its System Application}

\author{
Akihiro MARUTA \\ Graduate School of Engineering, Osaka University, 2-1 Yamada-oka, Suita, Osaka 565-0871
}

(Received March 11, 2009)

\begin{abstract}
Optical buffers are indispensable subsystems for implementing optical packet routers. Recently tunable optical delay lines based on slow light in optical fibers have been actively studied for application to optical buffers. The combination of tunable delay lines and wavelength conversion is highly effective for contention resolution. We recently proposed all-optical tunable delay lines using optical soliton's peculiar features exhibited in optical fibers. In this paper, we review the proposed all-optical tunable delay line that consists of a wavelength conversion based on soliton self-frequency shift and a filtering supercontinuum spectrum. We also introduce a non-integer ratio bit rate converter based on soliton collision as a system application of an all-optical tunable delay line.
\end{abstract}

Key Words: Optical fiber, Optical buffer, Optical delay line, Fiber nonlinearity, Optical soliton

1. はじめに

より高速で大容量の光ネットワークを実現するため に，光/電気/光変換を介さずに，データをやり取りする 全光ネットワークの実現が強く望まれている。そのよう なネットワークでは, 光のままでデータのスイッチング を行う光ルータが必要となる. 光バッファは光パケット の衝突を回避するために必須であり, 光ルータの実現に 欠かせないサブシステムである。一方で, 光ランダムア クセスメモリ (Random Access Memory: RAM)の実現が難 しいために, 現在でも光バッファの開発は十分とは言え ない. 近年, 光可変遅延線 (Tunable Delay Line: TDL)を 用いて光バッファを実現するための研究が盛んに行われ ている。これまでに誘導ブリルアン散乱 (Stimulated Brillouin Scattering: SBS $)^{1}$ ， 誘導ラマン散乱 (Stimulated Raman Scattering: SRS ${ }^{2)}$, 光パラメトリック増幅 (Optical Parametric Amplification: OPA) ${ }^{3)}$ ，ソリトン衝突4)などを 用いた光可変遅延線が提案されているが, 波形歪みを伴 うこと, 利用できる带域幅が狭いこと, あるいは遅延量 が少ないことなどの改善を要する点がある。また, 波長 変換とファイバの分散を利用した方法 ${ }^{5-7)}$ も提案されて いるが，SBS，SRS，OPAおよびソリトン衝突を用いた 技術と比較して構成が複雑になるという久点がある。最 近, 我々は, 光ファイバ中でのソリトン自己周波数シフ ト (Soliton Self-Frequency Shift: SSFS)を用いた全光可変
遅延線を提案した ${ }^{8)}$ 。一方，パケット衝突を回避する方 法として, 光バッファ以外に, 波長変換を用いる方法が ある ${ }^{9)}$. 波長変換によるパケット衝突回避の利点は, 遅 延が少ないことである。しかし，使用可能な波長数に制 限があることを考慮しなければならない年，そこで，光 可変遅延線と波長変換を併用することで，ルータ中での パケット衝突を大きく低減することができ，高効率の ルーティングが可能になると考えられる。本稿では, SSFSとスーパーコンティニューム (Supercontinuum: SC) 光のフィルタリングを用いる, 波長変換機能を有する全 光可変遅延線を紹介する. また, 全光可変遅延線のシス テム応用として，ソリトン衝突を用いた全光ビットレー 卜変換器 ${ }^{11)}$ について紹介する.

\section{2. 波長変換機能を有する全光可変遅延線の原理}

光パルスを, 異常分散值をもつファイバ(Anomalous Dispersion Fiber: ADF)に入射する場合について考える. この光パルスのパルス幅が1 ps以下であると仮定する と，ADFを伝搬するパルスの振る舞いは次式によって記 述できる。

$$
i \frac{\partial E}{\partial z}-\frac{\beta_{2}}{2} \frac{\partial^{2} E}{\partial t^{2}}+v|E|^{2} E=-i \gamma E+i \frac{\beta_{3}}{6} \frac{\partial^{3} E}{\partial t^{3}}+v t_{R} \frac{\partial|E|^{2}}{\partial t} E
$$


ここで，zは伝搬距離， $t$ は群速度で移動する時間， $E(z, t)$ $\left(|E|^{2}\right)$ は電界の複素包絡線振幅である。また,

$\beta_{2}=-\frac{\lambda^{2} D}{2 \pi c}$ : 群速度分散,

$\beta_{3}=\frac{(S \lambda+2 D) \lambda^{3}}{(2 \pi c)^{2}}$ : 三次分散,

$v=\frac{2 \pi n_{2}}{\lambda A_{\text {eff }}}:$ 非線形係数,

$t_{R}:$ ラマン応答時間,

$\gamma=\frac{\log _{e} 10}{20} \alpha:$ ファイバ損失

であり， $\lambda, D, S, n_{2}, A_{\mathrm{eff}}, \alpha$ はそれぞれ波長，分散パラ メー夕, 分散スロープ, 非線形屈折率, 実効コア断面 積, 損失係数を表す。また, $c$ は真空中における光速で ある. ADFではD >0であるので， $\beta_{2}<0$ である.（1）式 のソリトン解を

$$
\begin{aligned}
E(z, t)= & \sqrt{\frac{\left|\beta_{2}\right|}{v}} \eta(z) \operatorname{sech}\left[\eta(z)\left\{t-t_{0}(z)\right\}\right] \\
& \exp \{-i \Delta \omega(z) t+i \theta(z)\},
\end{aligned}
$$

と表すことにしよう。ここで, $\sqrt{\left|\beta_{2}\right| / v} \eta(z), \Delta \omega(z)$, $t_{0}(z), \theta(z)$ はそれぞれソリトンの振幅, 周波数, 時間位 置, 位相を表す。（2）式の解を仮定して (1) 式に摂動法 ${ }^{12)}$ を適用し，さらに， $z=0$ における初期值を $\eta(z=0)=1$ / $\tau_{s}, \Delta \omega(z=0)=t_{0}(z=0)=0$ とすると,

$$
\begin{aligned}
\eta(z) & =\frac{1}{\tau_{s}} \exp (-2 \gamma z), \\
\Delta \omega(z) & =\frac{t_{R} \beta_{2}}{15 \gamma \tau_{s}^{4}}[1-\exp (-8 \gamma z)], \\
t_{0}(z) & =\frac{t_{R} \beta_{2}^{2}}{120 \gamma^{2} \tau_{s}^{4}}[8 \gamma z-1+\exp (-8 \gamma z)] \\
+ & \frac{\beta_{3}}{7200 \gamma^{3} \tau_{s}^{2}}\left\{300 \gamma^{2}[1-\exp (-4 \gamma z)]+\frac{t_{R}^{2} \beta_{2}^{2}}{\tau_{s}^{6}}\right. \\
& {[16 \gamma z-3+4 \exp (-8 \gamma z)-\exp (-16 \gamma z)]\}, }
\end{aligned}
$$

を得る。ここで, $\tau_{s}=t_{s} / 2 \log _{e}(\sqrt{2}+1)=t_{s} / 1.763 て ゙ あ り, t_{s}$ は入射パルスの幅である. $\gamma=0, \beta_{3}=0$ の場合, (3) 式は

$$
\begin{aligned}
& \eta(z)=\frac{1}{\tau_{s}}, \\
& \Delta \omega(z)=\frac{8 t_{R} \beta_{2}}{15 \tau_{s}^{4}} z, \\
& t_{0}(z)=\frac{4 t_{R} \beta_{2}^{2}}{15 \tau_{s}^{4}} z^{2},
\end{aligned}
$$

となる.よって, ソリトンの振幅 $\eta$ は一定であり, 周波 数のシフト量は $z$ 抢よび $\eta^{4}$, つまり伝搬距離とソリトン のピーク電力の2乗に比例することがわかる. この現象 はソリトン自己周波数シフト (SSFS) と呼ばれている 13,14).さらに，時間位置もまたソリトンのピーク電力の 2乗に依存して変化する。 よって, ソリトンのピーク電 力を変えることにより, 遅延量を変化させることができ る.

Fig. 1に波長変換機能を有する全光可変遅延線の概略

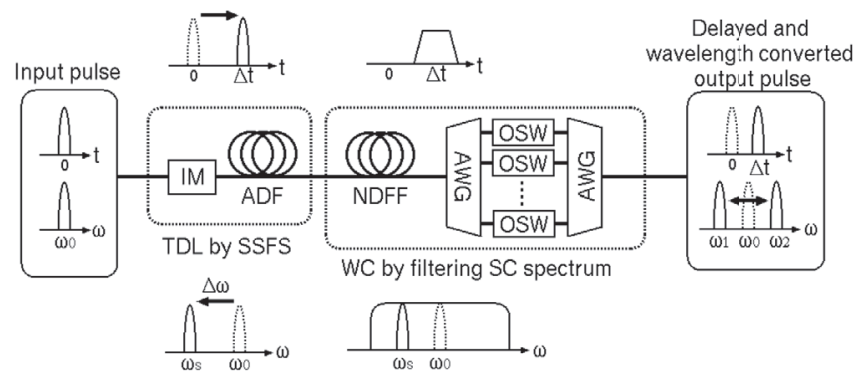

Fig. 1 Schematic diagram of all-optical tunable delay line accompanied with wavelength conversion.

を示す。その構成は2段階に分かれている。1段階目で は, 中心周波数が $\omega_{0}$ である光パルスのピーク電力を強度 変調器 (Intensity Modulator: IM) を用いて調整し，その 後，光パルスをADFに入射する，パルス幅が1 ps以下の 超短パルスであると仮定すると, ADF中でSSFSにより

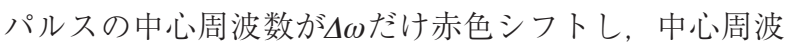
数が $\omega_{s}$ となる。 これに伴い光パルスは $\Delta t$ だけ遅延する. 遅延量は入力パルスのピーク電力の 2 乗に比例するため, IMで入力パルスのピーク電力を調整することにより, 任意の遅延量を得ることができる。2段階目では，SCに よるスペクトル拡がりを生じさせるために正常分散值を もつ分散フラットファイバ(Normal Dispersion Flattened Fiber: NDFF) に光パルスを入射する. NDFFの出力端で, 拡がったSCスペクトルをアレイ導波路形回折格子 (Arrayed Waveguide Grating: AWG)を用いてさまざまな周 波数成分に切り分け, 光スイッチ (Optical Switch: OSW) を用いて所望の周波数成分のみを切り出す。再びAWG によって結合し，最終的に $\Delta t$ 遅延した所望の中心周波数 をもつ光パルスを得る。提案する構成で用いるIMや OSWは, 非線形ループミラーやLN変調器などにより実 現できる.

\section{3. 単一パルスに対する原理確認実験}

波長変換機能を有する全光可変遅延線の実験系を Fig. 2に示す. ファイバレーザー(Fiber Laser: FL)から出

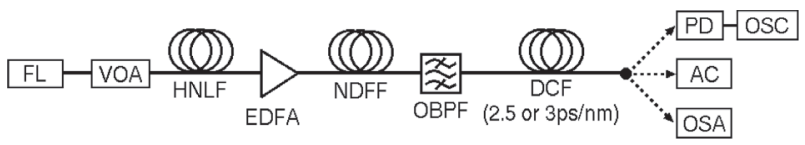

Fig. 2 Experimental setup for all-optical tunable delay line accompanied with wavelength conversion.

Table 1 Fiber Parameters of HNLF and NDFF at $1550 \mathrm{~nm}$ used in the experiment.

\begin{tabular}{ccc}
\hline Parameter & HNLF & NDFF \\
\hline Dispersion $[\mathrm{ps} / \mathrm{nm} / \mathrm{km}]$ & 2.2 & -1.93 \\
\hline Dispersion Slope $\left[\mathrm{ps} / \mathrm{nm}^{2} / \mathrm{km}\right]$ & 0.032 & -0.001 \\
\hline Nonlinearity $[1 / \mathrm{W} / \mathrm{m}]$ & 12 & 3.9 \\
\hline Loss $[\mathrm{dB} / \mathrm{km}]$ & 0.59 & 0.24 \\
\hline Length $[\mathrm{km}]$ & 2.4 & 1.5 \\
\hline
\end{tabular}


射した中心波長 $1545 \mathrm{~nm}$, 繰り返し周波数 $25 \mathrm{MHz}$, パル ス幅0.5 psのガウス形光パルスを高非線形ファイバ (Highly Nonlinear Fiber: HNLF) に入射する。このとき, 入力パルスのピーク電力を可変光減衰器 (Variable Optical Attenuator: VOA)によって変化させる. HNLF中でSSFS によって波長シフトおよび時間遅延の生じた光パルス を, SC光の発生に十分な光電力を得るために, エルビ ウム添加光ファイバ増幅器 (Erbium Doped Fiber Amplifier: EDFA）で増幅した後，NDFFに入射する．NDFFの出力 端で, SCスペクトルを帯域幅 $5 \mathrm{~nm}$ の光帯域通過フィル 夕 (Optical Band Pass Filter: OBPF) で切り出す.このと き, 中心波長は1525 nmから $1565 \mathrm{~nm}$ ま゙変化させた。 HNLFとNDFFのパラメータをTable 1に示す.NDFFで生 じる周波数チャープを補償するために, OBPFでフィル タリングを行った後に, 群遅延量 2.5 たは $3.0 \mathrm{ps} / \mathrm{nm}$ の 分散補償ファイバ(Dispersion Compensation Fiber: DCF) に光パルスを入射する. 最後に, DCFから出射した光パ ルスを50 GHzの帯域幅を持つ光検出器 (Photo Detector: PD) で光/電気変換し，その波形をサンプリングオシロ スコープ (Sampling Oscilloscope: OSC)で観測した.

Fig. 3 (a)に, HNLFへの入力ピーク電力が $2.5,4$, $5 \mathrm{~W}$ 場合の, DCFの出力端において観測された時間波 形を示す。 OBPFの中心波長は $1560 \mathrm{~nm}, \mathrm{DCF}$ 群遅延量 は2.5 ps/nmである。ただし，OSCにより観測した光パル スのパルス幅は実験で用いたPDの帯域制限により，実 際のパルス幅より広がっている. Fig. 3 (a)から, 入力 ピーク電力を $2.5 \mathrm{~W}$ から $5 \mathrm{~W}$ に増加させるに従い, 遅延 量が増加していることがわかる。また, いずれの入力 ピーク電力においても大きな波形劣化が生じていないこ とが分かる。なお，波形の右裾に見られる振動成分は， FLからの出射パルスを直接OSCで観測した場合にも見 られるため，PDおよびOSCでの帯域制限に起因するも のと考えられる. Fig. 3 (a) 中の挿入図は自己相関計 (Autocorrelator: AC) で観測した自己相関波形である。ペ デスタル成分は観測されず，波形劣化なしに光パルスを 遅延できていることが分かる. Fig. 3 (b) に, Fig. 3 (a) に対応するスペクトルを示す。点線と実線はそれぞれ HNLFの入力端とDCFの出力端において観測されたスぺ クトルを表す。いずれの入力ピーク電力に対しても, 中 心波長 $1560 \mathrm{~nm}$ に波長変換されていることが分かる。

Fig.4に, OBPFの中心波長を $1560 \mathrm{~nm}$ と, 入力ピー ク電力を変化させた場合の, 出力パルスの遅延量の変化 を示す. 白丸と破線はそれぞれ実験結果と (1) 式を数值 的に解いて得られた結果である. 数值計算では, 実験と 同じファイバパラメータとHNLFへの入射光パルスのパ ラメータを用いている。 なお, ラマン応答時間 $t_{R}$ は $3 \mathrm{fs}$ とした。実験で得られた最大遅延量は 15.6 psであった。

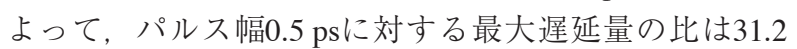
である。また，Fig. 4に示すとおり，実験とシミュレー ションの結果はよく一致している. Fig. 5に, 入力ピー ク電力を $2.5 \mathrm{~W}$, 中心波長を $1545 \mathrm{~nm}$ とし場合の出力パ ルスの遅延時間位置を基準時間 (遅延量 $=0$ ) とした時 の，各中心波長に打ける遅延量を示す。1525 nmから

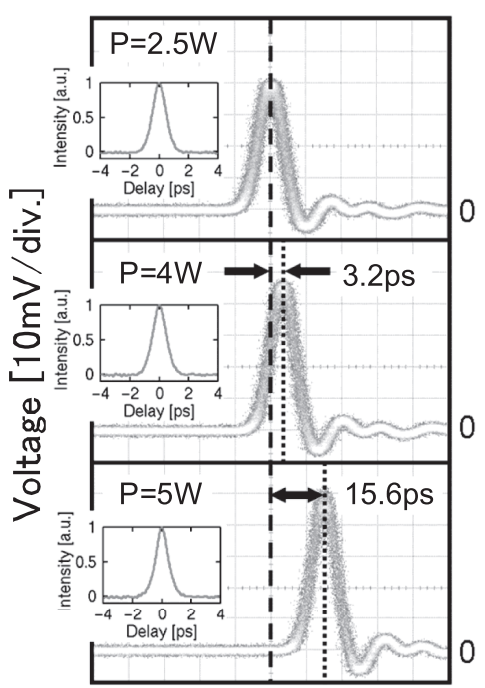

Time [10ps/div.]

(a) Temporal waveforms and autocorrelation traces

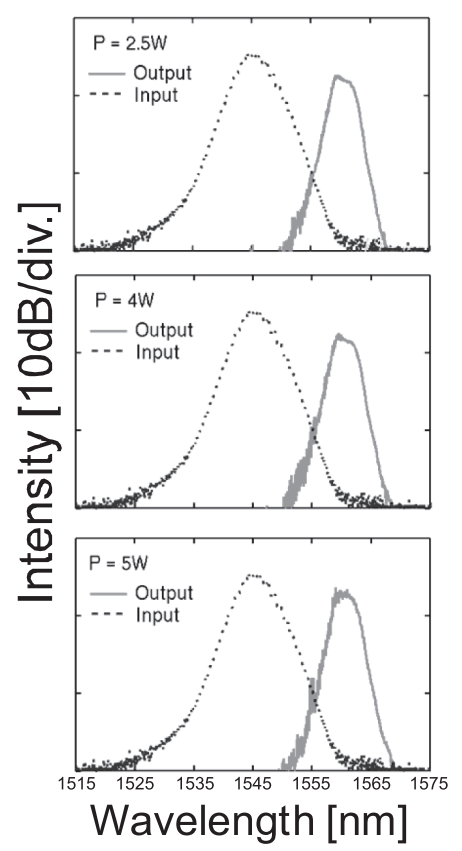

(b) spactra

Fig. 3 Temporal waveforms, autocorrelation traces, and spectra observed at the output of DCF.

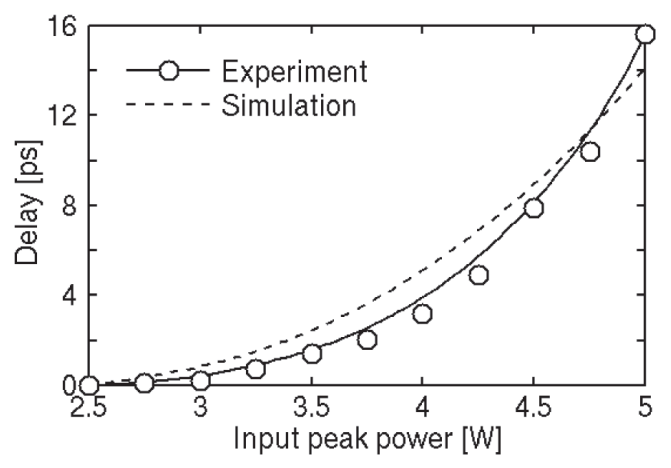

Fig. 4 Delay versus input peak power. 


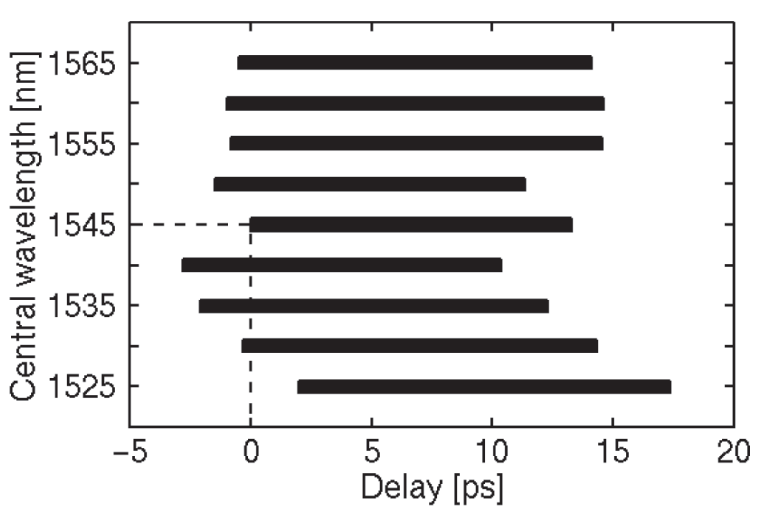

Fig. 5 Delay range for various center wavelengths.

$1565 \mathrm{~nm}$ な゙の波長変換と同時に，それぞれの中心波長 において平均で $14.4 \mathrm{ps}$ の時間遅延を観測することに成功 した。異なる中心波長間で遅延時間に差が生じる原因 は, DCF通過後の残留周波数チャープによる時間シフト である。実際のシステムでは, AWGによるフィルタリ ング後に各中心波長で適切な遅延量を組み込むことでこ の時間差を補償することができる.

\section{4. $10 \mathrm{Gbit} / \mathrm{s}$ でデータ変調されたRZパルス列に 対する全光可変遅延実験}

次に, $10 \mathrm{Gbit} / \mathrm{s}$, 符号長 $2^{31}-1$ の擬似乱数ビット列 (Pseudo Random Bit Sequence: PRBS) に対する全光可変 遅延動作の実験的検証を行った ${ }^{15)}$. パルスの圧縮・伸長 を付加した全光可変遅延線の概略をFig. 6に示す. 中心 周波数 $\omega_{0}$ のデー夕変調された入力パルスを, くし型プロ ファイルファイバ(Comb-like Profiled Fiber: $\mathrm{CPF})^{16)}$ を用 いてパルス圧縮した後, IMで入力ピーク電力を調節し,
$\mathrm{ADF}$ に入射する. SSFSによりパルスの中心周波数は $\omega_{\mathrm{s}}$ に赤方シフトし，同時に $\Delta t$ の時間遅延を得る。周波数シ フト量は入力ピーク電力の 2 乗に比例するため, IMを用

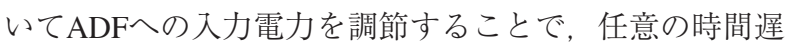
延を得ることができる。遅延したパルスをパルス伸長器 に入射することで，入力パルス幅と同じパルス幅をもつ 時間遅延したパルスを得ることができる.

Fig. 7に実験系を示す. 繰り返し周波数 $10 \mathrm{GHz}$ のモー ドロックレーザ(Mode-Locked Laser Diode: MLLD) から 中心波長 $1545 \mathrm{~nm}$ ，パルス幅 $2.0 \mathrm{ps}$ のパルス列が出射す る。 パルス列をLN強度変調器( LN-IM) とパルスパター ン発生器 (Pulse Pattern Generator: PPG)を用いて10 Gbit/s, 符号長 $2^{31}-1$ PRBS信号に変換する。デー夕変調された パルス列をEDFAで増幅し，CPFに入射することで，パ ルス幅を $0.4 \mathrm{ps}$ まて圧縮する. CPFへの入射平均電力は $17.8 \mathrm{dBm}$ である. VOAでピーク電力を調節し， HNLFに 入射LSSFSを発生させて時間遅延を得る。パルス幅を 元に戻すために，群遅延量 $-3.0 \mathrm{ps} / \mathrm{nm}$ のCFに入射す る.このとき, DCF出力でのパルスの幅は $5.0 \mathrm{ps}$ であっ た。 入射平均電力を $12.6 \mathrm{dBm}$ とした場合, $10.6 \mathrm{dBm}$ のと きのパルスの時間位置を基準として, DCF出力において $10.0 \mathrm{ps}$ の時間遅延が得られた。 Fig. 8に遅延量を変化さ せたときのビット誤り率(Bit Error Rate: BER) とアイパ ターンを示す。遅延量に関わらず，エラーフロアは確認 されず，良好なアイパターンが得られていることが分か る. $10.0 \mathrm{ps}$ の時間遅延に対して, 受信電力 $-25.5 \mathrm{dBm}$ で エラーフリー動作 $\left(\mathrm{BER}=10^{-9}\right)$ を確認した。

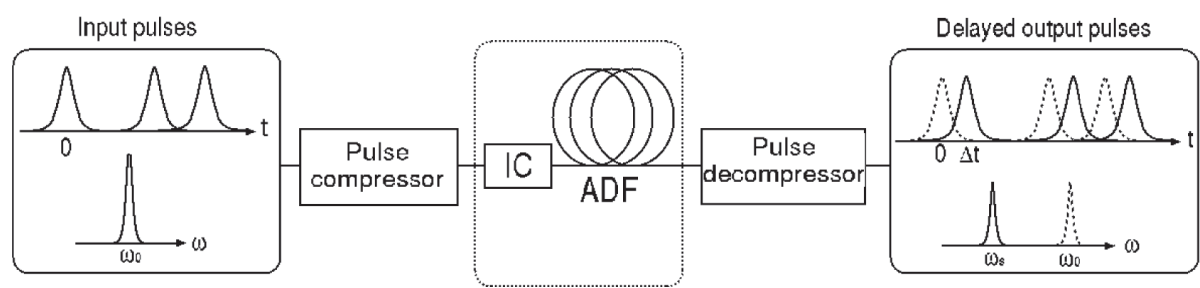

TDL by SSFS

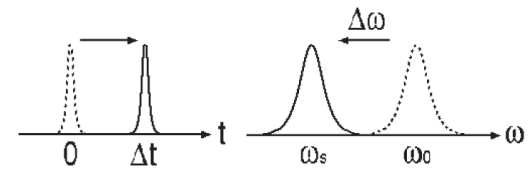

Fig. 6 Schematic diagram of all-optical tunable delay line associated with pulse compression and decompression.

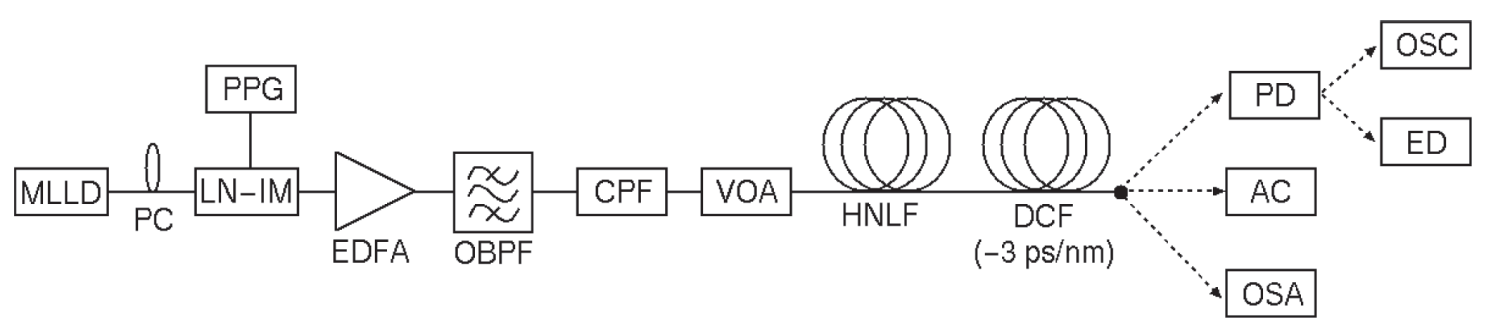

Fig. 7 Experimental setup for all-optical tunable delay line associated with pulse compression and decompression. 

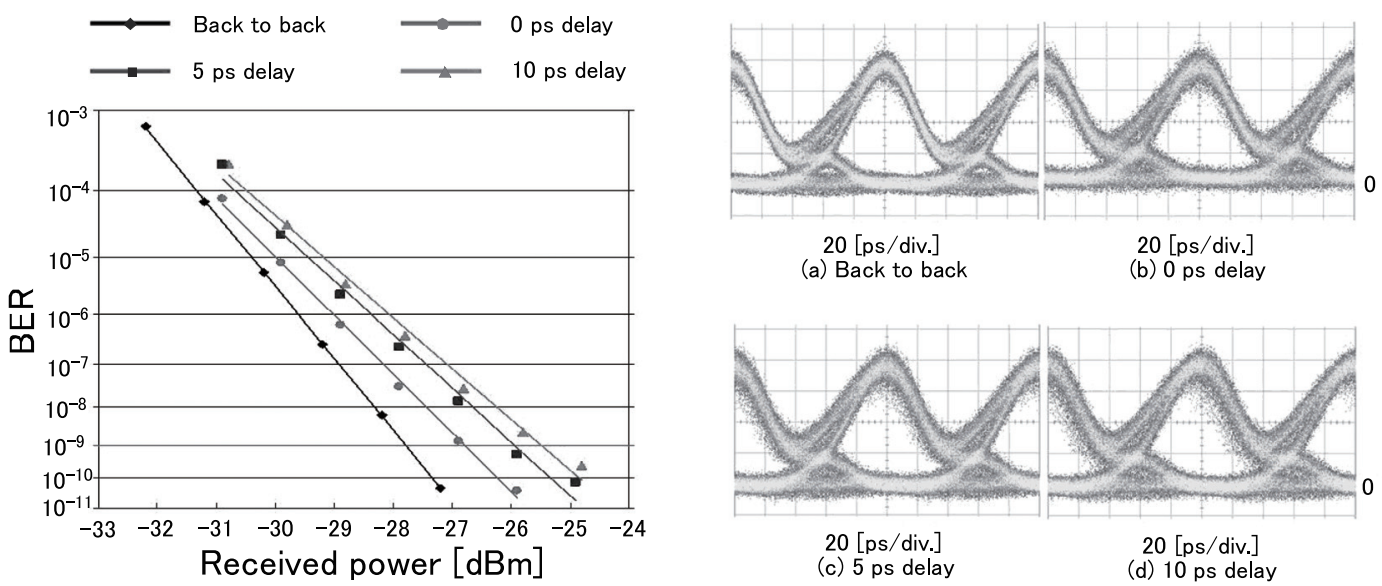

Fig. 8 BER curves and eye-patterns for different delays.

5. ソリトン衝突による時間シフトを利用した 全光ビットレート変換

最後に,ソリトン衝突を用いた全光可変遅延線()のシ ステム応用として, 全光ビットレート変換器 ${ }^{11}$ を紹介し よう。将来の全光ネットワークにおいては, 種々の誤り 訂正 (Forward Error Correction: FEC) 技術の利用による訂 正ビット数の違いにより，わずかにビットレートの異な る信号が混在することが考えられる。ネットワーク間を ビットレート無依存で接続するためには，光ノードにお いて, 入力信号を光信号のまま任意のビットレートに変 換する技術が重要となる。また，現在のFECエンコーダ (デコーダ)では, 光/電気変換を介しているため, FEC の処理速度は光信号の伝送速度に比べると低速である。 そこで，光信号のままでFEC処理を行う光FECの実現が 期待されており ${ }^{17)}$, 光FEC処理の実現のためにはビット レート変換技術が必要不可欠である。これまでの全光 ビットレート変換は, 光時分割多重 (Optical Time Division Multiplexing: OTDM) 信号に対する多重化/多重 分離技術としての研究開発が行われてきた。しかし，信 号を任意のビットレートに変換することができる技術は 未だ実現されていない，ところで，異なる周波数を持つ ソリトン同士が衝突する際，衝突前後で時間波形および 中心周波数は変化しないが, 衝突中の相互位相変調 (Cross Phase Modulation: XPM)によってソリトンの時間 位置がシフトする現象がある。時間シフト量はソリトン
パルスの振幅差, 周波数差, 衝突回数に依存する4).こ の現象を利用して全光ビットレート変換器を実現するこ とができる。

Fig. 9に全光ビットレート変換の原理図を示す。パル ス間隔が $t_{0}$ ，波長 $\lambda_{s}$ のつの信号光パルスの間にパルス間 隔 $t_{0}$, 波長 $\lambda_{c}$ の 3 つの制御光パルスを配置する。両者を光 カプラ (Optical Coupler: OC) で合波後, ADFに入射す る. $\lambda_{s}<\lambda_{c}$ の場合, 信号光パルスが制御光パルスを追い 抜くように衝突し，衝突回数に応じた時間シフトが発生 する。このとき, 後方の信号光パルスは3つの制御光パ ルスと衝突し，その時間シフト量を $3 \Delta t$ とすると，真ん 中のパルスは2つの制卸光パルスと衝突するので $2 \Delta t$, 前 方のパルスは1つの制御光パルスと衝突するので $\Delta t$ の時 間シフトが生じる。ADF出力では中心波長 $\lambda_{s}$ の $\mathrm{OBPF}$ 用いて，信号光パルス成分のみを取り出す。時間シフト 量は衝突する制御光パルスの個数によって異なるが，す ベてのパルス間隔は $t_{0}-\Delta t$ となり，ビットレートを増加 させることができる。Fig. 10に原理確認実験の実験系を 示す. FLから出射した中心波長 $1545 \mathrm{~nm}$, 繰り返し周波 数 $25 \mathrm{MHz}$ の光パルスを $3 \mathrm{~dB}$ のOCで分波し, 一方を信号 光パルス列発生系へ, 他方を制御光パルス列発生系入入 射する，両者ともほぼ同一の構成である。まず，1つの パルスを偏波無依存分岐遅延合波器(Split \& Delay Coupler: SDC)で，振幅のそろった複数のパルスに分割 する，次に，EDFAを用いて，基本ソリトンの形成に必 要な光電力となるようにパルスを増幅し, OBPFを用い

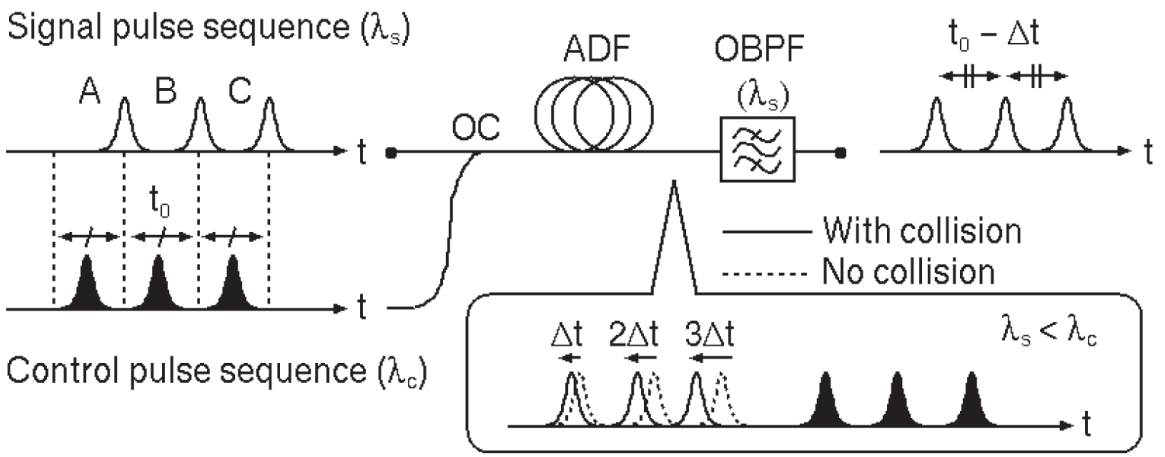

Fig. 9 Schematic diagram of all-optical bit rate converter. 


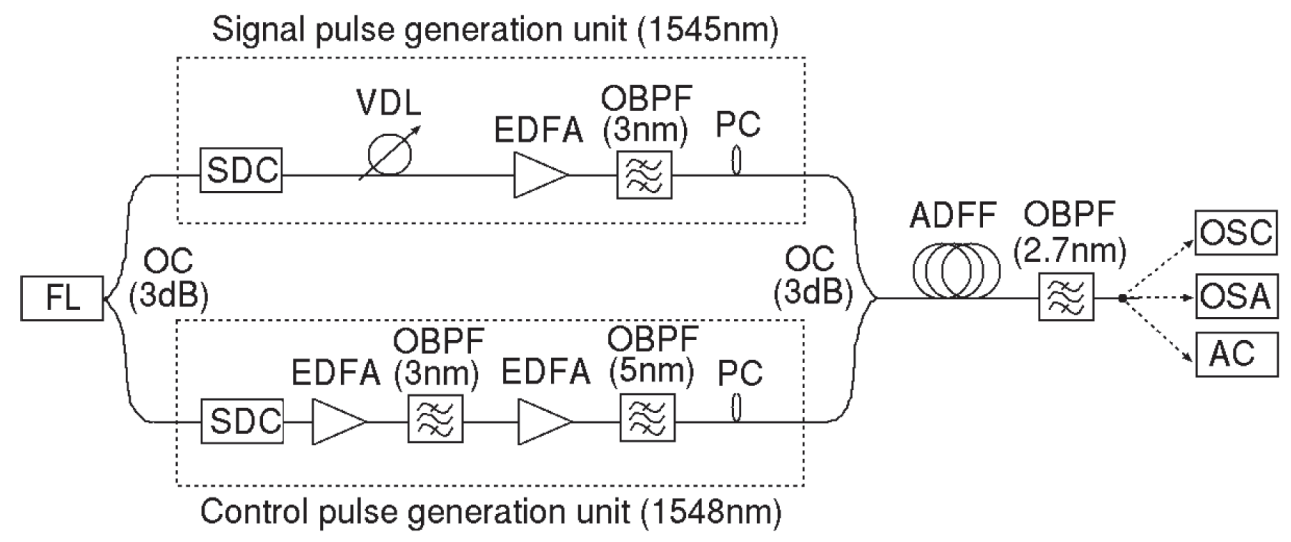

Fig. 10 Experimental setup for all-optical bit rate converter.

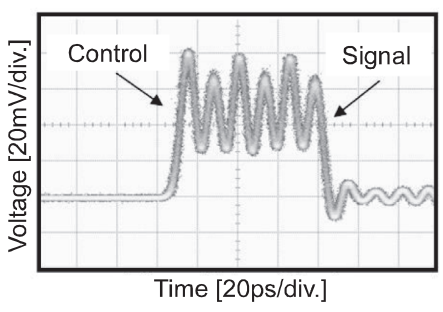

(a) Input of ADFF

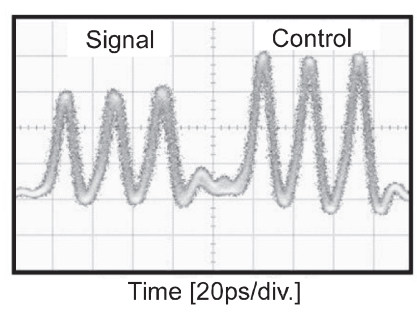

(b) Output of ADFF

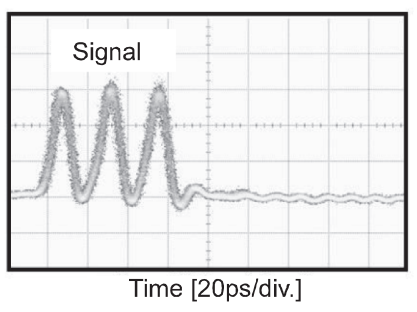

(c) Output of OBPF

Fig. 11 Observed temporal waveforms.

て信号光パルスおよび制御光パルスの中心波長をそれぞ れ1545 nm, $1548 \mathrm{~nm}$ とる。さらに, 可変遅延線 (Variable Delay Line: VDL)を用いて, 制御光パルスが信 号光パルスの間に位置するように初期位置を調節し，異 常分散フラットファイバ(Anomalous Dispersion Flattened Fiber: ADFF) に入射してソリトン衝突を発生させる。 $\mathrm{ADFF}$ の出力において1545 nmの中心波長をもつOBPFで 信号光パルス成分のみを取り出す. Fig. 11にADFF入出 力, OBPF出力の時間波形を示す. Fig. 11より ADFF内で 完全に衝突を終えて, OBPFで信号光パルスのみを取り 出せていることがわかる. Fig. 12に入出力での衝突の有 無による信号光パルス列の自己相関波形の違いを示す. 右の図は左図中の四角の点線で囲む部分の拡大図であ る. 実線は衝突あり, 点線は衝突なしの場合を示す. Fig. 12より入出力で信号光パルスの間隔が狭くなってい ることがわかる。ソリトン衝突が生じる場合, 信号光パ
ルスのビットレート(パルス間隔)は，入力で $45.45 \mathrm{Gbit} / \mathrm{s}$ $(22.00 \mathrm{ps})$, 出力で47.16 Gbit/s (21.20 ps)であった.よっ て, $1.71 \mathrm{Gbit} / \mathrm{s}(0.80 \mathrm{ps})$ のビットレート変換(時間シフ ト)を実現できていることがわかる。

6. まとめ

本稿では，まず，SSFSとSC光のフィルタリングを用 いた, 波長変換機能を有する全光可変遅延線を紹介し

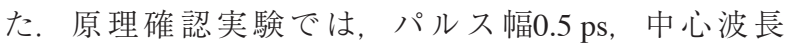
$1545 \mathrm{~nm}$ の入力パルスに対して, 最大 $15.6 \mathrm{ps}$ の遅延量を 観測し，Cバンド全域をカバーする $1525 \mathrm{~nm}$ か $1565 \mathrm{~nm}$ にわたる波長変換が可能であることを示した。 また，パ ルス圧縮器を前置することにより，10 Gbit/sのPRBS信 号に対して，エラーフリーで最大 $10 \mathrm{ps} の$ 遅延が得られ た。このような広範囲に及ぶ波長変換と光可変遅延線を
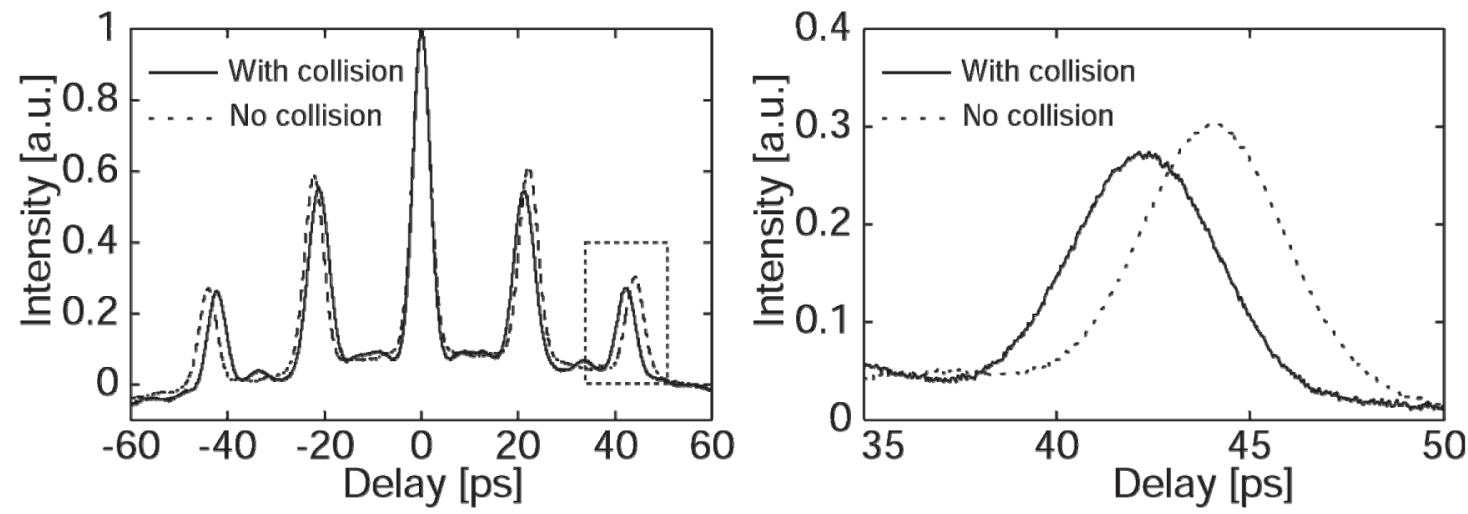

Fig. 12 Observed autocorrelation traces. 
併用することにより，将来の全光ネットワークにおける 光ルータ中でのパケット衝突を大幅に低減することがで きる。 また，大きな分散值を持つより長尺なファイバを 用いることで，容易に遅延量を増加させることが可能で ある。さらに，大きな非線形係数と大きな異常分散值を 持つ, 低損失かつ分散フラットな光ファイバの開発によ り, より短尺で大きな遅延量の得られる実用的な可変光 遅延線が実現できると期待している。 さらに, 全光可変 遅延線のシステム応用として, ソリトン衝突を用いた全 光ビットレート変換器を紹介した。 ビットレート

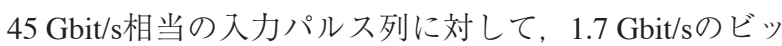
トレート変換を実現した。このような全光ビットレート 変換器を導入することにより，より柔軟な全光ネット ワークの設計が可能になると考えている。

\section{謝 辞}

本稿で示した成果は, 大阪大学大学院工学研究科の大 学院生であった小田祥一朗博士と国広隆志氏, 加納 知周 氏，および大学院生の冨岡省吾氏の協力によって得ら れたものである。記して，感謝いたします。また，パル ス圧縮用CPFを貸与いただいた古河電気工業(株)に感謝 いたします。

\section{参考文献}

1) K. Y. Song, M. G. Herraez, and L. Thevenaz: Opt. Express 13 (2005) 82.

2) J. E. Sharping, Y. Okawachi, and A. L. Gaeta: Opt. Express 13 (2005) 6092.

3) D. Dahan and G. Eisenstein: Opt. Express 13 (2005) 6234.

4) T. Kunihiro, A. Maeda, S. Oda, and A. Maruta: Opt. Express 14 (2006) 11736.

5) J. E. Sharping, Y. Okawachi, J. van Howe, C. Xu, Y. Wang, A. E. Willner, and A. L. Gaeta: Opt. Express 13 (2005) 7872.

6) J. van Howe and C. Xu: Opt. Express 13 (2005) 1138.

7) Y. Okawachi, J. E. Sharping, C. Xu, and A. L. Gaeta: Opt. Express 14 (2006) 12022

8) S. Oda and A. Maruta: Opt. Express 14 (2006) 7895.

9) A. Al Amin, K. Shimizu, M. Tanaka, T. Tanemura, R. Inohara, K. Nishimura, Y. Horiuchi, M. Usami, Y. Takita, Y. Kai, Y. Aoki, H. Onaka, Y. Miyazaki, T. Miyahara, T. Hatta, K. Motoshima, T. Kagimoto, T. Kurobe, A. Kasukawa, H. Arimoto, S. Tsuji, H. Uetsuka, and Y. Nakano: Proc. the European Conference on Optical Communication (ECOC), Cannes, France (2006) PD Th4.1.6.

10) K. Onohara, Y. Awaji, N. Wada, F. Kubota, and K. Kitayama: IEEE Photon. Technol. Lett. 17 (2004) 627

11）加納 知周, 富岡省吾, 国広隆志, 丸田 章博：電子情報通 信学会光通信システム研究会 (2008) OCS-2008-79.

12) A. Hasegawa and Y. Kodama: Solitons in optical communications, Chapter 5, Oxford University Press, Oxford (1995).

13) F. M. Mitschke and L. F. Mollenauer: Opt. Lett. 11 (1986) 659.

14) J. P. Gordon: Opt. Lett. 11 (1986) 662.

15) T. Kanou, T. Kunihiro, and A. Maruta: Proc. OSA Topical Meeting on Slow and Fast Light, Boston, Massachusetts, USA (2008) SMC4.

16) T. Inoue, Y. Taniguchi, J. Hiroishi, T. Yagi, and Y. Mimura: Proc. the European Conference on Optical Communication (ECOC), Berlin, Germany (2007) PO-013.

17）鈴木昌弘，植之原裕行：電子情報通信学会通信ソサイエ ティ大会 (2007) B-12-2.

\section{光ソリトン自己周波数シフト効果}

\section{(soliton self-frequency shift)}

石英系光ファイバのラマン利得は, ポンプ光の周波数 に対して周波数が低くなるに従って増加し, 約 $13 \mathrm{THz}$ 低い周波数で最大となる。一方, 光パルスのパルス幅が 狭くなるに従ってスペクトル幅が広がり, 誘導ラマン効 果によって, 単一パルス内で, 高周波側のスペクトル成 分がポンプ光となって, 低周波側のスペクトル成分を増 幅し，光パルスの搬送波周波数が低周波側にシフトする 現象が観測される。この現象を自己誘導ラマン効果とい う. 特に，分散值が一定の異常分散ファイバ中を伝搬す
る光ソリトンパルスの場合には，パルス形状を保持した ままで，ピーク電力の2乗および伝搬距離に比例して， その中心周波数が低周波側にシフトする。この現象を光 ソリトン自己周波数シフト効果という。ささらに，異常分 散性を介して周波数シフトが時間位置のシフトに変換さ れ，ピーク電力の2乗および伝搬距離の2乗に比例した時 間遅れが生じる。この効果は，パルス幅が数ピコ秒以下 の場合に顕著となる。

(丸田 章博) 